\title{
The Role of Radiotherapy Among the Therapeutic Options for Castleman's Disease
}

\section{Castleman Hastalığının Tedavi Seçenekleri Arasında Radyoterapinin Rolü} \author{
Emine Bağır ${ }^{3}$, Melek Ergin ${ }^{3}$, Semra Paydaş2 \\ ${ }^{1}$ Çukurova University Faculty of Medicine, Department of Radiation Oncology, Adana, Turkey \\ ${ }^{2}$ Çukurova University Faculty of Medicine, Department of Medical Oncology, Adana, Turkey \\ ${ }^{3}$ Çukurova University Faculty of Medicine, Department of Pathology, Adana, Turkey
}

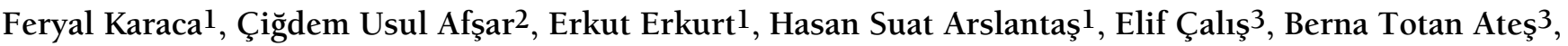

\section{To the Editor,}

Castleman's disease, also known as giant lymph node hyperplasia or angiofollicular lymph node hyperplasia, was first defined in 1956 by Castleman and his colleagues. It usually appears as a mediastinal, cervical, mesenteric, or retroperitoneal mass [1]. Castleman's disease is divided into 2 different types, hyaline vascular or plasma cell, based on histopathological features [2]. Cases with mixed histological features have also been reported $[3,4]$. There are 2 clinical types: localized or multicentric [3]. There is also another form associated with HIV positivity.

Castleman's disease may be accompanied by malignant lymphoma, vascular neoplasm, follicular dendritic cell tumor, or Kaposi's sarcoma [5,6,7]. The localized form is usually asymptomatic; surgical removal of the lesion is curative and it does not progress to lymphoma or other diseases. However, the multicentric form usually appears as the plasma cell type, leads to systemic complaints, and is treated medically $[8,9]$. Multicentric Castleman's disease is quite aggressive and may progress to non-Hodgkin's lymphoma. The localized hyaline vascular type is the most common and it clinically presents with abdominal, mediastinal, and cervical masses. We present here a 15-year-old female patient with a neck mass for 6 months who presented with enlargement of the mass for the last 2 months and shortness of breath at night. On physical examination, palpation revealed a hard, fixed, and indeterminably circumscribed mass extending to the mediastinum. Laboratory tests showed no cytopenia. Upon magnetic resonance imaging of the soft tissue of the neck and thorax, a soft mass of $9 \times 5 \times 6 \mathrm{~cm}$ was detected. The patient underwent lymph node excision for diagnostic purposes. The pathological report revealed hyaline vasculartype Castleman's disease (Figure 1). The patient was considered to be inoperable since the mass was large and

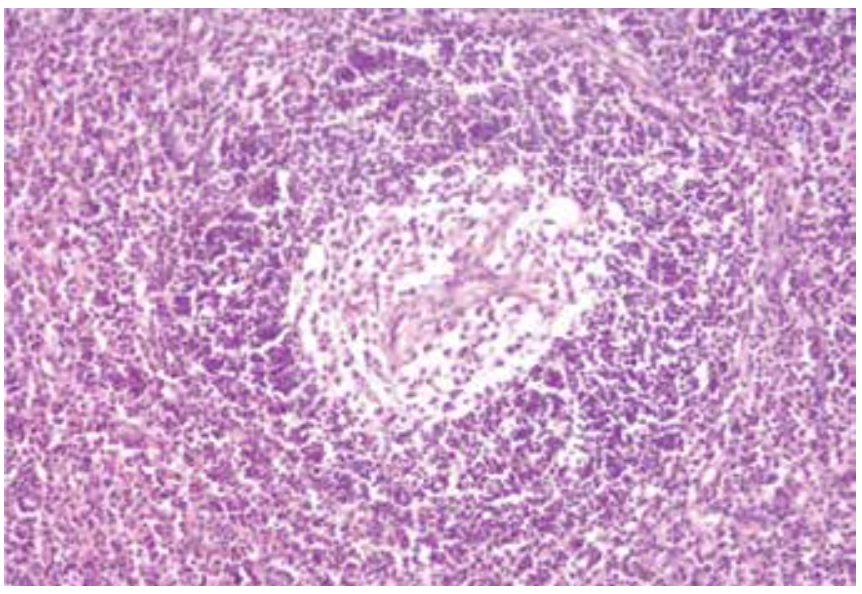

Figure 1. Appearance under light microscope with $H \& E$ staining and 20x magnification.

Address for Correspondence: Çiğdem USUL AFŞAR, M.D.

Çukurova University Faculty of Medicine, Department of Medical Oncology, Adana, Turkey

Phone: +90 32233860 60/3142 E-mail: cigdemusul@yahoo.com 
fixed to the surrounding tissues. After giving a total dose of 3060 cGy external radiotherapy (RT) to the left neck and supraclavicular lymph nodes in 17 fractions of $180 \mathrm{cGy}$, a total dose of 4500 cGy curative RT was given by boost to the involved lymph nodes. On the control computed tomography examination, in comparison to the previous imaging, partial regression was observed and the mass was $5 \mathrm{~cm}$ in the axial plane. The patient has been followed for 18 months and the disease is still stable. Systemic inquiry of the patient revealed no symptoms. In Castleman's disease of the localized form, prognosis is excellent with surgical resection of well-circumscribed neck masses [3]. However, the present patient had no chance of surgery.

Adjuvant therapy is needed for the cases in which resection is not available or incomplete [10]. A study performed at the MD Anderson Cancer Center, including 22 patients, investigated the role of RT in unicentric and multicentric disease. The paper reported that RT provided clinical response and cure in the selected patients [11]. Cure has been achieved after resection in all cases in the literature [12]. Unlike the localized form, there is no consensus on the treatment of the multicentric form. Chemotherapy and corticosteroid therapy are given in addition to surgery; however, response is variable and prognosis is poor.

In conclusion, Castleman's disease should be considered in the front line of possibilities in the differential diagnosis of mediastinal masses. Complete resection by surgery results in excellent early and late outcomes. As in the present case, RT is an appropriate option for masses that cannot be resected by surgery. RT can be a definitive treatment modality of unicentric Castleman's disease with a good control rate and few complications, as seen in a review of the literature [13]. Three-dimensional conformal RT and intensity modulated radiation therapy can also be used in unresectable unicentric cases [14]. The overall response rate in localized Castleman's disease is about $70 \%$ (complete response rate is about $44 \%$ and partial response rate is $29 \%$ ), and almost all responding patients sustain stable or remission status. Only a few cases show no response to RT. As the techniques of RT have developed, it is possible to deliver high-dose radiation to target tumors with minimal complications [13].

\section{Conflict of Interest Statement}

The authors of this paper have no conflicts of interest, including specific financial interests, relationships, and/ or affiliations relevant to the subject matter or materials included.

Key Words: Castleman's disease, Radiotherapy, Unicentric

Anahtar Sözcükler: Castleman hastalığı, Radyoterapi, Unisentrik

\section{References}

1. Frizzera G. Castleman's disease and related disorders. Semin Diagn Pathol 1988;5:346-364.

2. Keller AR, Hochholzer L, Castleman B. Hyaline-vascular and plasma-cell types of giant lymph node hyperplasia of the mediastinum and other locations. Cancer 1972;29:670683.

3. Herrada J, Cabanillas F, Rice L, Maning J, Puph W. The clinical behavior of localized and multicentric Castleman disease. Ann Intern Med 1998;128:657-662.

4. Weysenburger DD, Nathwany BN, Wynberg CD, Rappaport H. Multicentric angiofollicular lymph node hyperplasia: a clinicopathologic study of 16 cases. Hum Pathol 1985;16:162-172.

5. Chan JKL, Tsang WYW. Follicular dendritic cell tumor and vascular neoplasm complicating hyaline-vascular Castleman's disease. Am J Surg Pathol 1994;18:517-525.

6. Gerald W, Kostianovsky M, Rosai J. Development of vascular neoplasia in Castleman's disease. Report of seven cases. Am J Surg Pathol 1990;14:603-614.

7. Dickson D, Ben-Ezra JM, Reed J, Flax H, Janis R. Multicentric giant lymph node hyperplasia, Kaposi's sarcoma, and lymphoma. Arch Pathol Lab Med 1985;109:1013-1018.

8. Hsu SM, Waldron JA, Xie SS, Barlogie B. Expression of interleukin-6 in Castleman's disease. Hum Pathol 1993;24:833-839.

9. Herbelin C, Roux-Lombard P, Herbelin A, Peuchmaur M, De Groote D, Griscelli C, Dayer JM, Prieur AM. Inflammation: "a natural experiment" for the systemic pathogenicity of cytokines. Eur Cytokine Netw 1998;9:57-60.

10. Ozkan H, Tolunay S, Gozu O, Ozer ZG. Giant lymphoid hamartoma of mediastinum (Castleman's disease). Thorac Cardiovasc Surg 1990;38:321-323.

11. Chronowski GM, Ha CS, Wilder RB, Cabanillas F, Manning J, Cox JD. Treatment of unicentric and multicentric Castleman disease and the role of radiotherapy. Cancer 2001;92:670676.

12. Li YM, Liu PH, Zhang YH, Xia HS, Li LL, Qu YM, Wu Y, Han SY, Liao GQ, Pu YD. Radiotherapy of unicentric mediastinal Castleman's disease. Chin J Cancer 2011;30:351-356.

13. Noh OK, Lee SW, Lee JW, Kim SY, Kim CS, Choi EK, Kim JH, Ahn SD. Cases report of unicentric Castleman's disease: revisit of radiotherapy role. Radiat Oncol J 2013;31:48-54.

14. Matthiesen C, Ramgopol R, Seavey J, Ahmad S, Herman T. Intensity modulated radiationtherapy (IMRT) for the treatment of unicentric Castlemans disease: a case report and review of the use of radiotherapy in the literature. Radiol Oncol 2012;46:265-270. 